\title{
Copyright in Academic Writings: Yours to Have and to Hold (and From Which a Publishing Contract Need Not Make You Part)
}

Jane Ginsburg

By submitting a manuscript, an author acknowledges that it is not being considered, nor will be submitted, for publication elsewhere, and agrees that the sole copyright is transferred to the publisher. This transferal is revoked if and when the publisher decides not to publish the manuscript. The publisher's copyright covers the exclusive right to reproduce and distribute the article by any means intended or effectively used to make it available for inspection, reading, or consultation, including, but not limited to, printing, reprinting, photocopying, and electronic means. The publisher grants the author, however, the right to have the submitted manuscript available on the author's own homepage and on public noncommercial servers such as http: //arxiv. org. [Acta Mathematica copyright policy (emphasis supplied), http://www. mittag-1effler.se/publications/ acta/instruction/submission.php

This journal copyright policy stands at the midpoint of overreach: not as objectionable as some academic publishing contracts, which require the publisher's written permission before the author may even quote substantially from her work, but less author-friendly than those (including the AMS

Jane Ginsburg is professor of literary and artistic property law at Columbia University. Her email address is ginsburg@1aw. columbia. edu.

Members of the Editorial Board for Scripta Manent are: Jon Borwein, Thierry Bouche, John Ewing, Andrew Odlyzko, Ann Okerson.

DOI: http://dx.doi.org/10.1090/noti873 standard form) that allow the author to retain copyright. It raises two questions, which I will address in the following comments: (1) By asserting that your submission transfers the copyright (a claim both overreaching and legally incorrect), the policy assumes that you initially own the copyright in your manuscript. For U.S. academics, is that in fact true? (2) Does the policy take more control over the author's work than is necessary and reasonable? My analysis addresses U.S. copyright law; other countries' copyright laws may differ (and some may be more author-protective).

\section{Initial Ownership of Academic Writings}

Professors are employed by universities. The U.S. copyright law prescribes that works created by employees in the scope of their employment are "works made for hire" whose copyright belongs to the employer. Does it therefore follow that professors do not own the copyrights in their scholarly writings? While the text of the copyright act, if applied literally, would suggest that result, a long-standing "teacher exception" to the work for hire rules preserves the professor's copyright ownership. As Judge Easterbrook of the Federal Court of Appeals for the Seventh Circuit (which sits in Chicago) contended:

A University "requires" all of its scholars to write. Its demands-especially the demands of departments deciding whether to award tenure-will be "the motivating factor in the preparation of" many a scholarly work. When [plaintiff's dean] told [plaintiff] to publish or perish he was not simultaneously claiming for the University a copyright on the ground that the work had become a "requirement or duty" within 
the meaning of [the university policy]. The University concedes in this court that a professor of mathematics who proves a new theorem in the course of his employment will own the copyright to his article containing that proof. This has been the academic tradition since copyright law began.

Judge Richard Posner, also of the Seventh Circuit, in a different case raising the academic copyright issue, corroborated Judge Easterbrook's view. Esteemed jurists, both Judges Posner and Easterbrook are also former members of the faculty of the law school of the University of Chicago (and still teach there) and as a result may not have been the most disinterested arbiters. Nonetheless, their assessments probably remain the most authoritative interpretations of the current copyright statute. Judge Posner wrote:

[V]irtually no one questioned that the academic author was entitled to copyright his writings. Although college and university teachers do academic writing as a part of their employment responsibilities and use their employer's paper, copier, secretarial staff, and (often) computer facilities in that writing, the universal assumption and practice was that (in the absence of an explicit agreement as to who had the right to copyright) the right to copyright such writing belonged to the teacher rather than to the college or university. There were good reasons for the assumption. A college or university does not supervise its faculty in the preparation of academic books and articles, and is poorly equipped to exploit their writings, whether through publication or otherwise; we may set to one side cases where a school directs a teacher to prepare teaching materials and then directs its other teachers to use the materials too.

Accordingly, many (perhaps most) university copyright ownership policies recognize professors' ownership of their scholarly works. For example, the Columbia University policy states: "By longstanding custom, faculty members hold copyright for books, monographs, articles, and similar works as delineated in the policy statement, whether distributed in print or electronically. This pattern will not change. This copyright policy retains and reasserts those rights." (http://www. columbia. edu/cu/provost/docs/copyright.htm7) ${ }^{1}$ Before signing a contract transferring any exclusive rights under copyright to a journal or other publisher, however, the academic author should verify that her university does not claim that the author's employment status vests or assigns copyright ownership in the university, lest the academic author grant rights that are not hers to give away.

\section{Contracts Transferring Copyright}

Assuming, however, that the academic author does own the copyrights in her scholarly articles and books, she can grant them to a publisher. But that does not mean that she should. Many academic and journal publishers ask for a complete transfer of rights; this is almost always more than they reasonably require to disseminate the work and to protect their interests in it. Some academics rather blithely sign away a broad swath of rights and then ignore the contract's restrictions on a variety of activities, from making their works available on a publicly accessible website to reworking (I won't say "recycling") portions of the published article into subsequent publications with other publishers. These academics appear to follow the Nathan Detroit approach to copyright compliance: "So sue me, sue me, what can you do me?" While they may correctly assume that the publisher is not likely to haul them into court, the better practice would allocate rights in their works in a way that the scope of the contract grant is not so overreaching as to force the granting authors to violate the terms of the contract when the authors want to make a reasonable, noncompeting, use of their writings.

Here are a few rules to take into account in determining whether a publishing contract is reasonable (or, for that matter, legally valid). First, any grant of exclusive rights must be made in writing and signed by the author. (As a result, notwithstanding the Royal Swedish Academy of Sciences' pretentions, as stated in the Acta Mathematica copyright policy, merely submitting your manuscript does NOT in fact divest you of the copyright.)

Second, copyright is "divisible": that is, you don't have to transfer all your rights under copyright; you can grant some exclusive rights and withhold others. For example, you can grant the exclusive right of first publication of your article in

\footnotetext{
${ }^{1}$ For a similar policy, see Washington University in St. Louis, Intellectual Property Policy 3(b) (2008), http: //www. wust1.edu/policies/intelprop.html\#sectioni.

The creator shall retain ownership of the following:

1. ...

2. All rights in artistic, literary and scholarly intellectual property, such as scholarly books, articles, and other publications (including those in electronic form), works of art, literature and music recordings are owned by their creators despite the use of University resources so long as such works are neither created under the direction and control of the University, nor developed in the performance of a sponsored research or other third party agreement.
} 
a journal but reserve the right to republish that article, perhaps together with other articles, in book form. You can impose conditions on the grant: for example, you authorize the publisher to transfer some or all of its rights to another publisher but subject to your approval of the successor or sublicensee publisher. (Requiring the publisher to notify you and obtain your agreement in those instances can matter, particularly if the identity of the publisher is important to you. For example, you signed an agreement with Prestige Publisher but didn't notice that the contract allowed the publisher to transfer its rights to Podunk Publisher.) You can also grant exclusive journal publication rights, but the journal grants back to you a nonexclusive license to make a variety of uses (paragraph 4 of the AMS Consent to Publish reflects this approach).

Third, under U.S. copyright law, you cannot bring a copyright infringement action unless you own an exclusive right under copyright. That is why most publishers seek a grant of exclusive rights: if the copyright is infringed, they want to be able to enforce it. And the author probably would prefer that the publisher incur the cost of the action. But, because copyright is "divisible", the author doesn't have to give the publisher everything in order to enable the publisher to sue to protect its rights. You can still withhold rights that you would like to exercise on your own or with a different publisher if those rights don't compete with the rights you're granting the first publisher, or you can at least provide for a grant-back to you of those rights.

For more information and for a database of different kinds of publishing contracts (not just academic journal and book publishing contracts), see www . keepyourcopyrights .org, a website launched by the Kernochan Center for Law, Media and the Arts, and the Center for Law and Technology at Columbia Law School. The site offers basic information about copyright (with links to more information) and a catalogue of contracts whose rights-granting clauses the site explains in plain English. The site also rates the contracts on a scale of "author-friendly" (signaled with a green thumbs-up), "could be worse" (signaled with a yellow thumb in equipoise), "author-unfriendly" (indicated by an orange thumbs-down), and "incredibly overreaching" (designated by a big red claw). The contracts are categorized by type of grant and type of creator. The site includes the full contracts in order to place the granting language in context. There is also a "before and after" section showing the contract language originally proposed and the final version after the author pushed back. It is important to recognize that many publishers and other co-contractant exploiters rely on authors' ignorance or intimidation, but if an informed author requests changes, more often than not, the changes will be accepted.
Recent volumes from MS

Advanced Studies in Pure Mathematics http://mathsoc.jp/publication/ASPM/

Volume 62

Arrangements of Hyperplanes -Sapporo 2009

Edited by H. Terao (Hokkaido)

and S. Yuzvinsky (Oregon)

ISBN 978-4-931469-67-9

Volume 61

Exploring New Structures

and Natural Constructions

in Mathematical Physics

Edited by K. Hasegawa

(Tohoku), T. Hayashi (Nagoya),

S. Hosono (Tokyo) and Y. Yamada (Kobe)

ISBN 978-4-931469-64-8

Volume 60

Algebraic Geometry in East Asia

-Seoul 2008

Edited by J. Keum (KIAS), S. Kondō (Nagoya),

K. Konno (Osaka) and K. Oguiso (Osaka)

ISBN 978-4-931469-63-1

MSJ Memoirs

http://mathsoc.jp/publication/memoir/memoirs-e.html

Volume 26

Hierarchy of

Semiconductor Equations:

Relaxation Limits with

Initial Layers for Large

Initial Data:

S. Nishibata (Tokyo Tech)

and M. Suzuki (Tokyo Tech)

ISBN 978-4-931469-66-2

Volume 25

Monte Carlo Method, Random Number, and

Pseudorandom Number:

H. Sugita (Osaka) ISBN 978-4-931469-65-5

Volume 24

Godbillon-Vey Class of Transversely

Holomorphic Foliations:

T. Asuke (Tokyo) ISBN 978-4-931469-61-7

$\nabla \nabla \nabla$ For purchase, visit $\quad \nabla \nabla \nabla$

http://www.ams.org/bookstore/aspmseries

http://www.worldscibooks.com/series/aspm series.shtml

http://www.worldscibooks.com/series/msjm_series.shtml

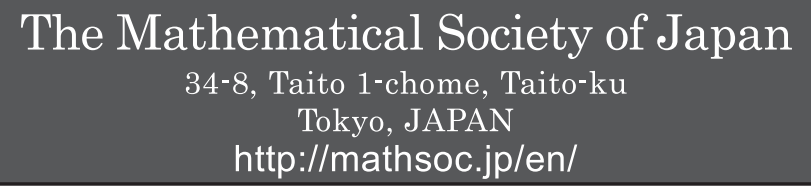

